\title{
Lisik: Lima Pilar Kebijakan Internal Kepala RA Al Hijrah Badrul Ulum dalam Menciptakan Iklim Belajar Kondusif
}

\author{
Muhammad Rifa'i $i^{\circledR}$, Muhammad Shaleh Assingkily² \\ Manajemen Pendidikan Islam, Universitas Islam Negeri Sumatera Utara \\ Pendidikan Guru Madrasah Ibtidaiyah, Universitas Islam Negeri Sumatera Utara \\ DOI: $10.31004 /$ obsesi.v5i2.1098
}

\begin{abstract}
Abstrak
Lisik adalah singkatan dari lima pilar kebijakan internal RA Al Hijrah Badrul Ulum, yakni Leadership, Ikhlas, Solid, Integritas dan Komunikatif. Penamaan lisik, didasarkan pada ungkapan bahasa Gayo yang berarti "rajin". Tulisan ini bertujuan untuk menganalisa program lisik dan aspek harmonisasi sivitas lembaga dalam menciptakan iklim belajar kondusif di RA Al Hijrah Badrul Ulum. Penelitian ini menggunakan pendekatan kualitatif dengan metode studi kasus. Data diperoleh menggunakan teknik wawancara secara langsung dan melalui WhatsApp, serta observasi dan dokumentasi. Selanjutnya, data dianalisis menggunakan teknik reduksi data, display data dan menarik simpulan. Keabsahan data diperoleh dari teknik triangulasi. Hasil penelitian ini menunjukkan bahwa kebijakan internal Kepala RA Al Hijrah Badrul Ulum dengan konsep lisik mampu menciptakan iklim belajar kondusif, hal ini ditandai melalui keselarasan temuan dan teori belajar efektif (kondusif) Gilbert H. Hunt, (1) harmonisasi antar warga RA, (2) kesadaran dalam mendidik anak sebagai amanah Allah swt.; dan (3) pengelolaan pendidikan yang efektif.
\end{abstract}

Kata Kunci: iklim belajar; kebijakan internal; kondusif; lisik.

\begin{abstract}
Lisik stands for the five pillars of RA Al Hijrah Badrul Ulum's internal policies, namely Leadership, Ikhlas, Solid, Integrity and Communicative. The name lisik, is based on the Gayo language expression which means "diligent". This paper aims to analyze the physical program and harmonization aspects of the institution's community in creating a conducive learning climate at RA Al Hijrah Badrul Ulum. This research uses a qualitative approach with a case study method. Data obtained using interview techniques directly and via WhatsApp, as well as observation and documentation. Furthermore, the data were analyzed using data reduction techniques, data display and drawing conclusions. The validity of the data was obtained from the triangulation technique. The results of this study indicate that the internal policy of the Head of RA Al Hijrah Badrul Ulum with the physical concept is able to create a conducive learning climate, this is indicated by the alignment of findings and the theory of effective learning (conducive) Gilbert H. Hunt, (1) harmonization between RA citizens, (2) awareness in educating children as a mandate of Allah SWT .; and (3) effective education management.
\end{abstract}

Keywords: Learning Climate; Internal Policy; Conducive; Lisik.

Copyright (c) 2021 Muhammad Rifa'i, Muhammad Shaleh Assingkily

$\triangle$ Corresponding author:

Email Address: muhammadrifai@uinsu.ac.id (Medan-Sumatera Utara, Indonesia)

Received 21 January 2021, Accepted 3 February 2021, Published 5 February 2021 


\section{PENDAHULUAN}

Kebijakan internal merupakan acuan prinsipil sivitas lembaga dalam meningkatkan mutu pendidikan (Alfiansyah, et. al, 2020). Acuan ini dimaksudkan untuk menyelaraskan kebijakan nasional dengan kultur lembaga, sehingga masing-masing lembaga pendidikan dapat mudah beradaptasi dengan berbagai kebijakan nasional.

Pimpinan memiliki peranan penting dalam memajukan citra dan meningkatkan mutu lembaga (Djafri, 2020; Sudrajat, et.al., 2021). Dalam konteks ini, dibutuhkan suatu gagasan dari pimpinan yang disepakati sebagai kebijakan internal. Dengan demikian, pimpinan bersama segenap sivitas lembaga dapat mengimplementasikan pengelolaan yang berbasis pada potensi internal lembaga (Pratiwi, 2016), serta mengacu pada "rambu-rambu nasional" (baca: kebijakan nasional pendidikan). Menurut Akbar (2018), kebijakan internal pimpinan lembaga (kepala sekolah) juga dapat meningkatkan kompetensi guru. Lebih lanjut, Mardlotillah (2013) menerangkan pentingnya kebijakan internal dalam upaya pengembangan pendidikan karakter. Mendukung kebijakan internal, Solichin (2015) menyampaikan pentingnya kombinasi kebijakan internal sebagai alternatif memenuhi kebutuhan masyarakat terhadap pendidikan secara nasional. Kerap kali, kebijakan pendidikan nasional diimplementasikan secara kaku, untuk itu dibutuhkan peran pimpinan dalam membangun kultur dan iklim "berani berkreasi" untuk kemajuan lembaga (Supriadi, 2011).

Atas dasar pentingnya kebijakan internal dalam menyahuti kebijakan nasional tentang praktik pendidikan di suatu lembaga, banyak lembaga pendidikan mulai dari jenjang RA/TK hingga pendidikan tinggi (universitas, institut, sekolah tinggi atau akademi) menyepakati kebijakan internal untuk meningkatkan mutu lembaga.

Lebih lanjut, Alfiansyah, et.al. (2020) menyebut kebijakan internal sebagai pedoman khusus yang hanya dimiliki oleh masing-masing lembaga, dengan 3 (tiga) manfaat, yaitu: (1) menjadi ciri khas program lembaga, (2) meningkatkan mutu lembaga dan (3) menciptakan citra positif lembaga pada masyarakat. Menyikapi pentingnya kebijakan internal, kepala RA Al Hijrah Badrul Ulum Kutacane Aceh Tenggara menerapkan suatu kebijakan yang telah disepakati bersama yang diberi nama lisik. Lisik itu sendiri merupakan singkatan dari Leadership, Ikhlas, Solid, Integritas dan Komunikatif.

Secara historis, lisik diiniasiasi oleh Bu Darma Taksiah, S.Pd.I. (Kepala RA Al Hijrah Badrul Ulum) sejak awal menjabat di RA tersebut, per tahun 2016 lalu. Menurut penuturan kepala RA tersebut, penamaan lembaga ini ditujukan sebagai upaya mewujudkan harmonisasi, kesadaran mendidik sebagai suatu amanah dan semangat belajar bagi anak di RA Al Hijrah, sebab arti dari lisik (bahasa Suku Gayo) yaitu "rajin". Akronim lisik ini sejatinya diambil oleh Bu Darma (Kepala RA) dari ungkapan yang lazim dalam percapakan masyarakat suku Gayo (sebagai suku mayoritas sivitas Warga RA tersebut) yakni lisik kati ara (rajin agar ada, sukses, dan seterusnya). Alasan mendasarnya, agar lisik dapat mudah diingat dan dipraktikkan oleh seluruh warga RA.

Berdasarkan keterangan salah satu guru di RA tersebut yakni bu Jumrah, bahwa nama ini sengaja dipilih oleh Bu Kepala RA karena menurut beliau 5 (lima) kepanjangan dari lisik itu adalah pilar suksesi lembaga yang harus dipedomani oleh seluruh guru dan siswa RA. Lebih lanjut, implementasi program lisik tersebut setiap tahunnya menuai banyak perubahan di RA Al Hijrah Badrul Ulum. Dengan demikian, kebijakan internal ini menjadi program yang membawa kebaikan dan kemaslahatan bagi RA Al Hijrah Badrul Ulum dalam upaya meningkatkan iklim belajar kondusif.

Sejatinya, kajian mengenai kebijakan internal pimpinan lembaga pendidikan telah diteliti oleh sejumlah akademisi atau peneliti dari berbagai aspek. Di antaranya mengkaji dari aspek peningkatan mutu lembaga (Alfiansyah, et. al, 2020; Pratiwi, 2016), standar proses pembelajaran (Puspitasari, 2018), peningkatan kompetensi guru (Akbar, 2018), penciptaan iklim belajar kondusif (Aryanti, 2010; Kurniawan, 2017), manajemen sekolah berbasis karakter (Hidayat, 2012), pengembangan pendidikan karakter (Mardlotillah, 2013), implementasi kebijakan pendidikan dan peran birokrasi (Solichin, 2015), pengelolaan sarana dan prasarana 
sekolah (Tanggela, 2013), implementasi program gerakan literasi sekolah (Wandasari, 2017), implementasi program sekolah Adiwiyata (Rahmah, 2014) dan upaya mewujudkan sekolah (lembaga) unggulan (Sumintono, 2013).

Berdasarkan literature review di atas, diketahui bahwa terdapat "bilik kosong" analisis kebijakan internal dari aspek harmonisasi sivitas lembaga dan upaya menciptakan iklim belajar yang kondusif, khususnya di era pandemi covid-19. Dengan demikian, dibutuhkan penelitian lebih lanjut, yang terangkum dalam judul, "Lisik: Lima Pilar Kebijakan Internal Kepala RA Al Hijrah Badrul Ulum dalam Menciptakan Iklim Belajar Kondusif”. Melalui penelitian ini, diharapkan akan diperoleh suatu rujukan baru tentang upaya harmonisasi pendidikan melalui kebijakan internal yang digagas oleh pimpinan lembaga dan disepakati oleh sivitas lembaga pendidikan. Lebih lanjut, kulturisasi dengan menggunakan istilah "daerah" tentu menjadi semangat tersendiri dalam "membumikan" kebijakan internal. Bahkan, dapat menjadi prototipe bagi lembaga setingkat lainnya untuk mengkreasikan ide dan gagasan dalam menciptakan iklim belajar kondusif yang baik dan ramah bagi anak usia dini.

\section{METODOLOGI}

Penelitian ini menggunakan pendekatan kualitatif dengan metode studi kasus. Menurut Yin (2009: 25) metode penelitian ini tepat digunakan untuk mengeksplorasi hal-hal yang bersifat kontemporer. Oleh sebab itu, studi kasus dipilih peneliti, sebab penelitian ini bertujuan untuk mengeksplorasi kebijakan internal RA berupa konsep atau program lisik yang bersifat kontemporer dan baru dalam menciptakan iklim belajar kondusif bagi anak usia dini. Penelitian ini dilakukan pada bulan Oktober s/d Desember 2020.

Pengumpulan data dilakukan dengan teknik wawancara mendalam secara individual, baik secara langsung maupun tidak langsung (melalui media smartphone), observasi partisipan melihat ruangan guru dan siswa yang terdapat sosialisasi secara tertulis tentang program lisik dan studi dokumentasi sebagai data yang "menyempurnakan" keabsahan penelitian. Upaya ini dilakukan dengan memperhatikan protokol kesehatan, sehingga alternatif via WhatsApp dan platform media sosial lainnya sangat membantu proses pengumpulan data. Selanjutnya data dianalisis dengan teknik (1) reduksi data, yakni memilah data yang dibutuhkan dalam penelitian, sedangkan data atau informasi yang "agak" jauh dari fokus penelitian maka difilter; (2) display data, tahap ini, data sebelumnya disajikan kembali oleh peneliti dalam bentuk susunan informasi yang naratif untuk memungkinkan penganalisaan data secara komprehensif, dan (3) penarikan kesimpulan.

Lebih lanjut, kerangka alur penelitian ditampilkan dalam gambar (1) di bawah ini.

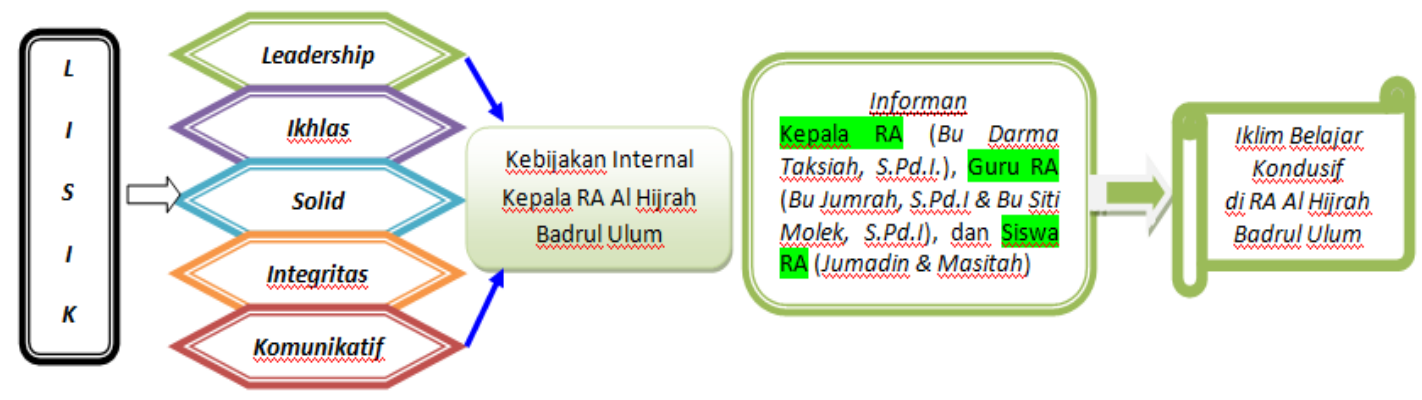

Gambar 1. Alur Penelitian (Logical Framework).

Selanjutnya, penjaminan validitas data penelitian dilakukan dengan teknik triangulasi. Triangulasi dilakukan dengan membandingkan hasil wawancara antara satu partisipan dengan yang lainnya pada tema yang sama (Creswell, 2009: 191). Adapun penggunaan teknik ini dimaksudkan untuk menjaring data dengan berbagai metode dan cara, lebih lanjutnya dengan menyilangkan informasi yang diperoleh agar data yang didapatkan lebih lengkap dan sesuai dengan yang diharapkan. 


\section{HASIL DAN PEMBAHASAN}

Pendidikan merupakan sistem pembentukan sumber daya manusia (SDM) unggul (Rasyid, 2015; Ningrum, 2016). Setiap bangsa sangat memperhatikan aspek pendidikan untuk kemajuan bangsanya, layaknya Indonesia dalam mukaddimah UUD 1945 termaktub, “... mencerdaskan kehidupan bangsa" (Supardi, 2015). Dalam konteks ini, dibutuhkan pengelolaan yang baik, terorganisir dan membudaya pada setiap lembaga pendidikan agar sistem tersebut dinamis, berkelanjutan dan berkesinambungan.

Kreasi dan inovasi menjadi dua kata kunci dalam mewujudkan sistem pengelolaan pendidikan yang adaptif terhadap berbagai perubahan dan kemajuan zaman (Widyaningrum \& Rahmanumeta, 2016). Kecanggihan teknologi dan dinamisasi ilmu pengetahuan menjadi suatu peluang yang harus dimanfaatkan oleh setiap pengelola lembaga pendidikan (Munir, 2018). Tidak hanya itu, kendala juga tentu dialami oleh pengelola pendidikan, termasuk di dalamnya kendala yang diakibatkan oleh covid-19.

Setiap pengelola lembaga pendidikan, tentu memiliki cara tersendiri dalam mengupayakan lembaganya (RA/TK, sekolah/madrasah) untuk tetap survive, adaptif dan sustainable menghadapi berbagai perubahan dan kendala atau hambatan (Maya \& Lesmana, 2018). Cara tersendiri pengelola ini dinamakan dengan kebijakan internal.

Kebijakan internal pada satuan RA/TK menunjukkan kesiapan pimpinan dan seluruh pihak untuk menyahuti kebijakan nasional yang tertera dalam kurikulum dan berbagai kebijakan Kementerian Pendidikan dan Kebudayaan RI (Yanto \& Fathurrochman, 2019: 123130; Saifuddin, 2015: 207-234). Jauh hari sebelum covid-19, Kepala RA Al Hijrah Badrul Ulum mengkonsep suatu program sebagai pilar-pilar utama dalam menciptakan iklim belajar kondusif dan mampu adaptif. Sebagaimana kutipan wawancara yang beliau sampaikan:

“...sebagai pimpinan, tentu saya dituntut 'turah' lebih visioner daripada guru, wali siswa apalagi siswa.

Oya kati kite gagas suatu program sebagai pilar utama i sekolah (RA) kite ni, gerale 'lisik'." (Hasil Wawancara dengan Darma Taksiah, S.Pd.I., Kepala RA Al Hijrah Badrul Ulum).

Kutipan wawancara di atas, menunjukkan bahwa program lisik adalah term atau istilah yang digagas oleh kepala RA dalam menampilkan bentuk ejawantah visinya sebagai pimpinan lembaga. Hal ini penting dilakukan oleh pemimpin lembaga pendidikan, untuk menerobos "celah-celah positif" untuk kemajuan mutu dan citra lembaga (Fitrah, 2017; Juliantoro, 2017).

Implementasi program lisik dilaksanakan secara lisan dan tertulis oleh pihak RA kepada guru dan juga siswa. Hal ini dimaksudkan agar program lisik terpatri bahkan menjadi karakter seluruh "warga RA". Selanjutnya, program lisik dibedakan menjadi 3 (tiga) bagian, sesuai dengan tupoksi dan tanggungjawab personalianya, yaitu lisik dalam memimpin (kepala RA), lisik dalam mendidik (guru) dan lisik dalam menuntut ilmu (siswa). Berikut penjelasan lebih lanjut.

\section{Historisitas Istilah Lisik di RA Al Hijrah Badrul Ulum}

Lisik merupakan istilah dari suku Gayo yang berarti "rajin" (Tillah, 2019). Pemberian terma ini didasari kultur setempat yang didominasi oleh masyarakat suku Gayo dan ungkapan yang lazim disampaikan "lisan ke lisan" oleh "orang Gayo" yaitu lisik kati ara.

Ungkapan lisik kati ara bermakna "rajin agar ada (berbekal)". Bila dimaknai lebih lanjut, ini merupakan pesan luhur dari masyarakat suku Gayo kepada anak muda bahkan diajarkan sejak usia dini, bahwa rajin adalah kunci mutlak dari kesuksesan (Sabariah, 2014). Terdapat pesan implisit dari ungkapan tersebut, yaitu orang yang ber-ada (sukses, kaya, senang, dan terma sejenis lainnya) hanya dapat diraih oleh mereka yang rajin bekerja, rajin belajar dan rajin berusaha.

Ketika diwawancarai, Kepala RA menuturkan bahwa penamaan lisik dicetuskan oleh beliau sendiri dan disandarkan pada istilah yang familiar di kalangan masyarakat suku Gayo. Dengan demikian, anak usia dini (siswa), guru, wali siswa dan pihak RA mudah mengingat, dan harapannya mengimplementasikan program lisik. 
Berdasarkan penuturan kepala RA, ungkapan inilah yang menginspirasi beliau untuk mencetuskan ide lisik dalam pengelolaan pendidikan di RA. Berikut kutipan wawancaranya:

“...Lisik kati ara, inilah pesan orangtua kite dahulu atau masa pudahna, bahwa rajin adalah kunci sukses. Giat atau rajin bukan hanya sekedar hadir dan diam, tapi berusaha semaksimal mungkin mewujudkan segala impian dan cita-cita. Itu makanya, RA kita inipun diberi label dan jargon penyemangat yaitu lisik, supaya semua yang belajar di sini jadi orang sukses." (Hasil Wawancara dengan Jumaiyah, S.Pd.I., Guru RA Al Falah)

Kutipan wawancara di atas, mengkonfirmasi bahwa istilah lisik diambil dari ungkapan luhur Gayo tentang upaya mencapai sukses. Lebih lanjut, Kepala RA juga menjelaskan tentang pentingnya karakter lisik bagi anak usia dasar. Sebab, merekalah generasi pelanjut estafet arah bangsa (baca: maju atau mundur). Hal ini senada dengan jawaban yang disampaikan oleh Siti Molek saat diwawancarai:

“... anak-anak RA di sini Pak, dominan orang suku kita Gayo. Walaupun dia tak suku Gayo, tapi sosial bergaulnya sudah Gayo. Jadi, sejak kecil mereka diajarkan untuk lisik atau rajin. Rajin belajar di RA makanya di-sekolahkan, juga rajin berladang pas hari libur. Karena ini kunci sukses yang diyakini oleh masyarakat Gayo turun-temurun. Makanya, Bu Kepala RA punya ide bagus dijadikan lisik sebagai program di RA kita ini agar maju Pak." (Hasil Wawancara dengan Siti Molek, S.Pd.I., Guru RA Al Hijrah Badrul Ulum)

Kutipan di atas, menegaskan bahwa secara historis, terma lisik diambil dari kultur masyarakat setempat yang meyakini "rajin" sebagai kunci kesuksesan. Di samping itu, ungkapan luhur "Lisik kati ara" menjadi inspirasi ide bagi kepala RA sebagai "ruh" dan semangat bersama dalam mendidik anak usia dini secara kondusif. Hal ini senada dengan pesan kearifan lokal didong masyarakat suku Gayo dalam membina anak untuk memiliki karakter rajin (lisik), sopan santun, mukemel, tertib, semayang-gemasih, genap-mupakat, alangtulung dan bersikekemelen (Daniah, 2019). Hanya saja, ide kreatif kepala RA yang membedakan penanaman nilai tersebut agar lebih melembaga dalam kebijakan program lisik di RA Al Hijrah Badrul Ulum.

Dengan demikian, dipahami bahwa lisik tidaklah nama atau istilah yang hadir begitu saja tanpa makna. Sebab, lisik adalah konsensus pihak RA Al Hijrah Badrul Ulum dalam mematrikan semangat "rajin" bagi sivitas RA melalui lima aspek, yaitu leadership, ikhlas, solid, integritas dan komunikatif.

\section{Implementasi Program Lisik}

Sebagaimana disebutkan pada poin sebelumnya, lisik merupakan singkatan dari leadership, ikhlas, solid, integritas dan komunikatif. Program ini digagas oleh Kepala RA sejak beliau menjabat di RA Al Hijrah Badrul Ulum tahun 2017 lalu. "ruh" dan semangat pendidikan bagi anak usia dini mendasari ide pimpinan untuk kesuksesan lembaga menghantarkan anak pada penggalian potensi diri terbaik mereka.

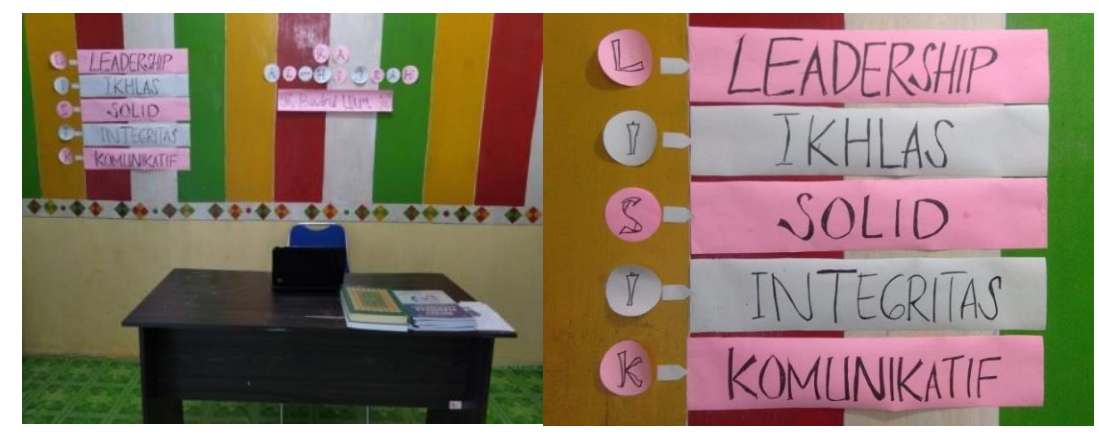

Gambar 2. Ruangan Guru Bertuliskan Program Lisik.

Berikut ditampilkan gambar 2, yang merupakan salah satu ruang guru yang terpampang tulisan program lisik. Gambar (2) merupakan "bukti terpampang" bahwa hampir setiap ruangan guru dihiasi secara kreatif untuk men-sosialisasikan program lisik di RA Al 
Hijrah Badrul Ulum. Lebih lanjut, implementasi program lisik diuraikan pada pembahasan berikutnya.

\section{Leadership}

Leadership atau kepemimpinan merupakan aspek penting yang harus dimiliki oleh setiap individu (Fata, 2012: 1-15). Tidak hanya kepala RA sebagai pimpinan lembaga, setiap "warga RA" penting memiliki jiwa kepemimpinan, baik guru maupun siswa. Urgensitas sikap kepemimpinan ini bak ibarat "gas dan rem" pada kendaraan. Di dalamnya terdapat kendali untuk bertindak secara arif atau diam dengan segala pertimbangan, sehingga tingkah laku seseorang menghasilkan karakter bijaksana dalam kesehariannya (Firdaus, 2017; Wahyu, 2020).

Kunci utama pengelolaan lembaga, terletak pada aspek kesadaran untuk memiliki jiwa dan sikap kepemimpinan (Hartono, 2020). Sebagaimana yang disampaikan Kepala RA, berikut kutipan wawancaranya:

“... dalam program 'lisik' ini, sengaja kita utamakan kesadaran pada setiap orang tentang pentingnya leadership atau kepemimpinan Pak. Gimana pula kite male mengendalikan orang lain, sedangkan dia tidak mau mengendalikan dirinya secara sadar. Nah, itulah maka penting leadership ini menurut saya Pak." (Hasil Wawancara dengan Jumrah, S.Pd.I., Kepala RA Al Hijrah Badrul Ulum)

Kutipan wawancara di atas, mempertegas peranan kepemimpinan (leadership) bagi setiap individu. Senada dengan kutipan di atas, Mukti (2018: 71-90) menerangkan bahwa titik kendali seseorang siap dipimpin dan siap memimpin terletak pada kesadarannya tentang kepemimpinan. Lebih lanjut, Marsalin (2020) menjelaskan bahwa terdapat keselarasan antara kepatuhan, integritas individu pada lembaga bila punya sikap kepemimpinan.

Mendukung hal di atas, Molek menyampaikan bahwa pada setiap rapat dan upacara resmi maupun informal di $\mathrm{RA}$, Bu Kepala senantiasa menyampaikan pentingnya suksesi program lisik, terutama aspek kepemimpinan. Sebab, ini titik kendali awal untuk 4 aspek lisik lainnya.

Ketika diwawancarai, salah satu siswa bernama Jumadin menuturkan, “... iya Pak, kami kee diminta 'lisik' oleh guru dan Bu Kepala. Kalo arti 'lisik' itu rajin Pak. Kalo mau sampai cita-cita kata pake ibu guru tu harus 'lisik' Pak." (Hasil Wawancara dengan Jumadin, Siswa RA Al Hijrah Badrul Ulum).

Berkaitan dengan upaya mematrikan sikap kepemimpinan, dibutuhkan keteladanan dan kegiatan lainnya, di antaranya menentukan ketua kelas, kegiatan baris-berbaris, pembagian kelompok bermain, dan pelatihan berbicara di depan kelas. Dengan demikian, siswa akan siap memimpin, siap dipimpin, memiliki sikap tenggang rasa dan keberanian di hadapan orang banyak, yang kesemuannya adalah bagian dari sikap kepemimpinan.

Berdasarkan uraian di atas, dipahami bahwa leadership sebagai salah satu bagian program lisik, memiliki peranan penting dalam menciptakan iklim belajar kondusif di RA Al Hijrah Badrul Ulum. Hal ini ditandai dengan upaya membangun kesadaran pentingnya sikap kepemimpinan pada sivitas RA, baik sikap siap memimpin, siap dipimpin, tenggang rasa dan juga keberanian.

\section{Ikhlas}

Ikhlas merupakan aspek kedua dalam program lisik di RA Al Hijrah Badrul Ulum. Menurut Hidayatullah (2018), Ikhlas adalah suatu sikap terpuji yang tidak tampak, letaknya di hati (qalbu). Begitupun, Chizanah \& Hadjam (2013: 39-49) menambahkan bahwa terdapat beberapa gejala keikhlasan hati seseorang, di antaranya berbuat tanpa pamrih, totalitas, dan akuntabel (tanggungjawab).

Senada dengan di atas, Kepala RA menuturkan:

"... kalau mendidik anak ini kan niatnya ibadah Pak, maka ikhlas tentu kunci yang harus kite ajar ku anak-anak kite, termasuk ikhlas guru pe mengejer. Gaji e tetap ara, sebagai jasa mengajar, dengan ikhlas tentu guru mendidik anak pe sayang lagu anak e kendiri. Begitu juga kepada anak, mereka harus ikhlas belejer, kati si i ejeri guru mudah masuk dan nangkap siswa Pak. Oya kati kite masukken ikhlas sebagai bagian dari konsep 'lisik' ni." (Hasil Wawancara dengan Jumrah, S.Pd.I., Kepala RA Al Hijrah Badrul Ulum) 
Kutipan di atas menunjukkan bahwa ikhlas menjadi bagian penting dari program lisik yang digagas Kepala RA, sebab ikhlas sangat mempengaruhi seluruh proses pendidikan yang berlangsung di RA. Menurut Aeni (2014), ikhlas adalah modal utama dalam menggerakkan roda dan proses pendidikan dengan baik. Tanpa ikhlas, pimpinan tidak akan mengayomi, guru tidak akan mendidik sepenuh hati, dan berpengaruh pada siswa yang tidak belajar dari hati.

Urgensitas ikhlas dalam pendidikan juga disebutkan oleh Assingkily \& Miswar (2020), penanaman karakter mulia atau akhlakul karimah pada anak akan dapat mudah diterima bila pendidik mengajar dengan keikhlasan hati. Mujib (2012) menyatakan pentingnya sikap ikhlas akan berpengaruh pada kemudahan anak menerima materi yang disampaikan, sebab sesuatu yang berasal dari hati akan sampai pada hati pula.

Mengingat kemajuan yang begitu pesat, Haq (2018) menginformasikan betapa banyak pendidik yang hanya mengajar dengan "lisan", dalam artian mengajar atau mendidik sebagai suatu kewajiban semata tanpa disertai upaya memotivasi agar anak dapat berkembang sesuai fase tumbuhkembang dan potensi yang dimilikinya.

Ketika diwawancarai, Darma Taksiah menuturkan:

“... iya Pak, dalam upacara resmi RA atau rapat bersama wali siswa, maka anak-anak, guru dan seluruh wali siswa yang hadir (menunggu anaknya) disampaikan oleh Bu Kepala tentang anak adalah amanah dari Allah swt., untuk itu harus ikhlas mendidik amanah sebagai tanggungjawab bersama, baik orang tua di rumah maupun kami para guru di RA ini." (Hasil Wawancara dengan Darma Taksiah, S.Pd.I., Guru RA Al Hijrah Badrul Ulum)

Mendukung kutipan di atas, Masitah salah satu siswa di RA Al Hijrah Badrul Ulum menyampaikan bahwa setiap masuk ke kelas atau kegiatan lainnya, Bu Kepala RA pasti menasihati, "bewenne anak-anakku harus lisik dan ikhlas belejer ya, kati sukses jadi guru, pilot, dokter, tentara, dan lain-lain." Motivasi semacam ini, sangat berpengaruh pada semangat belajar dan iklim belajar yang kondusif bagi anak di lingkungan belajar (sekolah).

Dengan demikian, dipahami bahwa pematrian ikhlas sebagai program yang membudaya di RA Al Hijrah Badrul Ulum memberikan sugesti kepada seluruh sivitas RA, tentang kesadaran mendidik bagi guru dan orangtua karena anak adalah amanah, begitu juga kepada anak bahwa belajar adalah ibadah yang bermanfaat bagi cita-cita mereka ke depan.

\section{Solid}

Solid adalah bagian ketiga dari program lisik di RA Al Hijrah Badrul Ulum. Solid ini dimaksudkan sebagai wujud kesatuan seluruh sivitas RA dalam menjalankan misi RA serta mencapai visi dan tujuan bersama. Sebagaimana yang disampaikan Kepala RA dalam kutipan wawancara berikut ini:

“... setelah menanamkan sikep kepemimpinen dan ikhlas kepada kite bewenne Pak. Maka solid ini penting. Mengapa? Karena ike guru-guru tidak akur, siswa tidak akur, pimpinan juga tidak akur, mau jadi apa lembaga ini. Maka kite programkan ini agar segala keterbatasan yang ada bisa saling melengkapi, pembelajaran kondusif dan anak-anak pun bisa belajar dengan tenang dan nyaman." (Hasil Wawancara dengan Jumrah, S.Pd.I., Kepala RA Al Hijrah Badrul Ulum)

Kutipan wawancara di atas, mengkonfirmasi pentingnya solid dalam satu lembaga. Menurut Jailani (2014), solid adalah "buah" dari kesadaran bersama tentang pentingnya keluarga. Bila sivitas lembaga memandang RA atau tempat mengajar sebagai lingkungan keluarga yang di dalamnya terdapat pimpinan keluarga, anak sebagai amanah dan dinamika kekeluargaan, maka akan timbul sikap amanah dan saling menjaga.

Senada dengan di atas, Molek menyatakan bahwa salah satu bagian dari lisik yang paling disenanginya sebagai guru adalah penanaman sikap 'solid'. Baginya, solid ini adalah kulminasi dari upaya memunculkan rasa tanggung jawab mendidik anak. Sebagaimana secara eksplisit disampaikan dalam kutipan wawancara berikut ini:

“... anak kita ini kan amanah dari Allah swt. kalo semua merasa ini tanggungjawab bersama pasti sangat bagus Pak. (1) Kita saling menjaga, artinya orangtua tidak menyalah-nyalahkan guru kayak di Berita Online, (2) saling kerjasama, artinya guru dan orangtua bisa saling koordinasi belajar anak di rumah dan di sekolah, (3) kita merasa memiliki, artinya, anak bersama jadi dididik juga secara bersama-sama 
tanpa harus menunggu inisiatif dari sepihak saja. Begitulah kira-kira Pak makanya saya setuju sekali dengan konsep harus solid ini." (Hasil Wawancara dengan Darma Taksiah, S.Pd.I., Guru RA Al Hijrah Badrul Ulum)

Mendukung kutipan di atas, Bagaimana tidak? Keluarga adalah tempat bernaung. Di dalamnya dibutuhkan kenyamanan dan kondusivitas. Begitulah analogi yang patut diberlakukan di RA atau lingkungan belajar, yakni iklim belajar kondusif. Dengan demikian, lembaga pendidikan bukanlah hal asing apalagi aneh bagi anak, melainkan menjadi "rumah kedua" yang tidak kalah nyamannya dengan rumah masing-masing.

Lebih lanjut, Thohir (2018: 203-222) menjelaskan kerjasama, saling menjaga dan merasa memiliki adalah kunci dari solidaritas yang terbina pada satu lembaga. Dalam konteks ini, ketiganya menunjukkan bahwa tidak ada pihak yang tidak terlibat untuk mendidik anak. Karena, mendidik menjadi panggilan hati (baca: amanah) yang harus disahuti untuk dididik bersama.

Berdasarkan uraian di atas, dipahami bahwa upaya menciptakan iklim belajar kondusif dalam program lisik salah satunya menumbuhkan sikap solid pada seluruh pihak, dengan ini akan terjalin kerjasama baik antara guru, pimpinan, wali siswa untuk mendidik anak, juga saling menjaga dan merasa memiliki di RA Al Hijrah Badrul Ulum.

\section{Integritas}

Integritas adalah bagian keempat dari program lisik di RA Al Hijrah Badrul Ulum. Lembaga yang kredibel, tidak hanya diisi oleh SDM unggul dan cerdas semata, dibutuhkan SDM yang berkarakter dan berintegritas (Inanna, 2018). Menurut Sarjana \& Khayati, (2016) integritas yang dimiliki oleh guru (pendidik) dapat me-mancarkan kewibawaan dan kejujuran pengelola dalam proses mendidik anak. Mewujudkan hal ini dibutuhkan budaya organisasi yang mendukung (baca: iklim belajar kondusif) dan kesejahteraan bagi pendidik. Untuk itu, peranan integritas tiap-tiap individu menjadi sentral dalam perwujudan iklim belajar yang kondusif.

Menurut Jumrah, dibutuhkan pematrian nilai dan sikap integritas pada seluruh sivitas RA sebagai "label diri" yang berkarakter dan patut diberi kepercayaan dalam mendidik anak, berikut kutipan wawancaranya:

“... sederhana saja kan Pak, bagaimana orang percaya menyekolahkan anaknya ke RA kita ini kalau orang-orang di dalamnya saja tidak berintegritas. Untuk itu, maka saya berupaya memulai dari individuindividu yang ada di RA kita ini Pak. Selebihnya, kita serahkan kepada guru-guru untuk membantu meningkatkan integritas lembaga, baik mutu anak (mampu perihal dasar dalam pendidikan), juga mutu berbentuk akreditasi RA." (Hasil Wawancara dengan Jumrah, S.Pd.I., Kepala RA Al Hijrah Badrul Ulum)

Berkaitan dengan kutipan di atas, Tidjani (2017: 96-133) menerangkan bahwa integritas adalah "garansi" orangtua menyekolahkan anaknya ke suatu RA/TK (sekolah/madrasah). Untuk itu, integritas menjadi aspek penting yang harus dimiliki oleh pendidik dan pengelola lembaga pendidikan.

Sejatinya, integritas yang diprogramkan oleh lembaga sifatnya tidaklah mutlak dapat mengubah karakter seseorang. Akan tetapi, Yusria (2018: 88-92) menerangkan bahwa program tersebut merupakan bagian dari upaya mewujudkan iklim kondusif bagi suatu lembaga. Dengan demikian, program lisik berupa integritas adalah upaya positif yang patut dikembangkan dan di-kulturisasi-kan di RA sebagai modal utama menanamkan 'rasa percaya' masyarakat kepada lembaga tersebut.

Lebih lanjut, program lisik ini diharapkan akan menjadi suatu rujukan baru tentang upaya harmonisasi pendidikan melalui kebijakan internal yang digagas oleh pimpinan lembaga dan disepakati oleh sivitas lembaga pendidikan, seperti yang digagas oleh pimpinan RA Al Hijrah Badrul Ulum. 


\section{Komunikatif}

Komunikatif adalah bagian kelima dari program lisik di RA Al Hijrah Badrul Ulum. Sikap komunikatif sangat penting untuk menjaga harmonisasi seluruh pihak dalam suatu lembaga. Hal ini yang mendorong Kepala RA menjadikannya 1 (satu) pilar untuk menciptakan iklim belajar kondusif, berikut kutipan wawancaranya:

“... iya Pak, kita juga menggagas ide agar seluruh pihak di RA ini dapat komunikatif. Tentu hal ini kita maksudkan agar terjalin rasa harmonis Pak di RA. Memang nampaknya mudah kali komunikatifini, tapi sulit juga Pak. Karena karakter tiap-tiap guru, tiap-tiap siswa apalagi wali siswa pasti berbeda-beda. Melalui program 'lisik' ini kita harapkan terpatri kesadaran sivitas RA betapa pentingnya untuk menumbuhkan sikap dan sifat komunikatif." (Hasil Wawancara dengan Jumrah, S.Pd.I., Kepala RA Al Hijrah Badrul Ulum)

Senada dengan kutipan di atas, Murni (2016) menyederhanakan makna komunikatif sebagai kunci dalam bersosialisasi. Interaksi sosial antar-individu, baik guru dengan siswa, siswa dengan teman sebaya, pimpinan dengan guru, pimpinan dengan siswa maupun wali siswa termasuk bagian dari komunikasi. Manusia sebagai makhluk sosial, mau tidak mau pasti akan berinteraksi dan membutuhkan individu lainnya. Untuk itu, sikap dan sifat komunikatif memegang peranan penting dalam kemampuan bersosialisasi seseorang. Sastrawan \& Primayana (2020) menambahkan, komunikatif juga kunci harmonis dalam hidup berkeluarga, bertetangga, bermasyarakat, berbangsa dan bernegara. Bagaimana tidak? Peperangan, konflik dan berbagai aspek kontradiktif lainnya, bermuara dari mis-komunikasi.

Mewujudkan iklim belajar yang kondusif, pimpinan RA dan para guru mengadakan musyarawah dan dialog terbuka bersama wali siswa untuk menjaga harmonisasi antar-pihak. Sebagaimana yang disampaikan Molek dalam kutipan wawancara berikut:

“... iya Pak, kami di sini diminta untuk transparan, dialog, dan musyawarah bila ada hal-hal yang ingin dilakukan. Tujuannya biasa Pak, agar kita terbuka dan ga ada yang ditutup-tutupi. Terlebih di sekolah ni kita kan sudah kayak saudara. Jadi, sudah semestinya kita saling tukar cerita untuk kebaikan bersama, khususnya masa depan dan perkembangan anak." (Hasil Wawancara dengan Siti Molek, S.P.I.I., Guru RA Al Hijrah Badrul Ulum)

Mendukung kutipan wawancara di atas, Handayani (2017) menyebutkan bahwa komunikatif tidak selalu berbentuk formal layaknya rapat dan musyawarah resmi. Melainkan dapat juga bersifat informal dengan penyampaian "lisan ke lisan" oleh guru atau pihak lainnya (Yuliana, 2012). Tujuannya, agar tidak terjadi mis-komunikasi yang menyebabkan gap antar-pihak di RA.

Berdasarkan uraian di atas, dipahami bahwa komunikatif memegang peranan penting dalam menciptakan iklim belajar kondusif. Sebab, antar-pihak saling terbuka dan mau bertukar pikiran dalam membantu proses tumbuhkembang anak. Dengan demikian, anak memperoleh kenyamanan belajar dalam bingkai "harmonis" di RA Al Hijrah Badrul Ulum.

\section{Lisik: Upaya Menciptakan Iklim Belajar Kondusif}

Sebagaimana poin hasil dan pembahasan sebelumnya, telah dipaparkan bahwa secara tekstual (makna leksikal bahasa Gayo) lisik bermakna 'rajin' serta secara kontekstual menjadi pilar utama dalam menciptakan iklim belajar kondusif di RA Al Hijrah Badrul Ulum. Secara eksplisit, dijelaskan 3 (tiga) bentuk upaya menciptakan iklim belajar kondusif melalui program lisik, yaitu (1) Kepala RA: lisik dalam memimpin, (2) Guru: lisik dalam mendik, dan (3) Siswa: lisik dalam menuntut ilmu.

\section{Kepala RA: Lisik dalam Memimpin}

Kepala RA Al Hijrah Badrul Ulum (bu Jumrah, S.Pd.I.) sebagai penggagas ide program lisik di lembaga tersebut, sudah sepatutnya menjadi sosok teladan dalam mengaplikasikan lisik pada proses pendidikan di RA. Hal ini dimaksudkan untuk men-stimulus guru dan siswa untuk ikutserta men-sukseskan program lisik.

Sejatinya, ada 3 (tiga) komponen lisik dalam memimpin yang diterapkan kepala RA, yaitu (1) lisik memberi teladan, (2) lisik memberi motivasi, dan (3) lisik memberi dukungan. Berikut penjelasannya lebih lanjut: 
Pertama, lisik memberi teladan. Maksudnya, Kepala RA dalam jabatannya sebagai pemimpin memberi teladan yang baik pada guru dan siswa. Hal senada disampaikan beliau ketika diwawancarai, "Secara sadar, saya harus memberi teladan kepada guru dan siswa dalam aplikasi program 'lisik' ini Pak. Mulai dari leadership, ikhlas, solid, integritas dan komunikatif." Menurut Wahyuni, et.al., (2020), suatu kebijakan internal di lembaga pendidikan, mustahil terwujud bila tidak dimulai dari keteladanan yang diberikan oleh pimpinan kepada guru dan siswa. Terlebih bagi anak usia dini, keteladanan yang dipraktikkan oleh orang dewasa akan lebih mudah diingat dan ditirukannya. Dengan demikian, keteladanan menempati posisi sentral dalam men-sukseskan program lisik di RA Al Hijrah Badrul Ulum.

Kedua, lisik memberi motivasi. Maksudnya, Kepala RA tidak sekadar menampilkan pribadi yang baik pada guru dan siswa, ia juga bertindak secara pro-aktif memotivasi guru dan siswa untuk ikut andil mengaplikasikan program lisik. Adapun bentuk motivasi yang diberikan kepala RA kepada pihak guru yaitu, (1) memberi apresiasi bagi guru yang produktif, aktif, dan komunikatif berupa intensif (bonus dari 'kantong pribadi') atau hadiah yang dibagi per-semesternya; dan (2) memfasilitasi guru untuk meningkatkan kemampuannya dalam pelatihan yang dilaksanakan oleh Kemenag atau internal RA. sedangkan bentuk motivasi yang diberikan kepala RA kepada siswa yaitu, (1) mengapresiasi siswa yang berprestasi di bidang akademik dan non-akademik.

Ketiga, lisik memberi dukungan. Maksudnya, kepala RA mendukung segala kegiatan akademik dan non-akademik yang diusulkan guru atau diikuti oleh siswa, dengan catatan selaras dengan aspek leadership, ikhlas, solid, integritas, dan komunikatif. Adapun bentuk dukungan yang diberikan terbagi dua, yaitu material dan non-material. Dukungan material berupa bonus kinerja dan memfasilitasi peningkatan mutu lembaga, sedangkan dukungan nonmaterial berupa apresiasi verbal. Menurut Sakban, et.al., (2019: 93-104), dukungan sangat berarti bagi bawahan. Faturahman (2018: 1-11) menambahkan dukungan dari pimpinan lembaga adalah bentuk perhatian dari atasan kepada bawahan. Perhatian melalui dukungan yang diberi oleh pimpinan akan meningkatkan kinerja guru dan mobilitas belajar siswa serta iklim yang kondusif dalam suatu lembaga pendidikan.

Dengan demikian, lisik dalam memimpin yang dilaksanakan oleh Kepala RA Al Hijrah Badrul Ulum menjadi "semangat tersendiri" yang diberi pimpinan untuk men-sukseskan program lisik. Adapun bentuk implementatifnya dibagi kepada tiga hal, yaitu keteladanan, motivasi dan dukungan.

\section{Guru: Lisik dalam Mendidik}

Guru adalah "ujung tombak" pendidikan. Peranannya dalam proses pendidikan sangat sentral, di mana setiap hari belajar di lingkungan sekolah, guru berinteraksi langsung dengan siswa (Heriyansyah, 2020). Interaksi langsung ini pulalah yang menjadikan guru memiliki kedekatan emosional tersendiri dengan masing-masing siswanya.

Atas dasar perannya yang begitu sentral, guru RA Al Hijrah Badrul Ulum juga diupayakan untuk men-sukseskan program lisik. Adapun aspek lisik yang di-'gaung'-kan yaitu lisik dalam mendidik. Secara leksikal, ini diartikan dengan "rajin dalam mendidik". Lebih komprehensif, Kepala RA menerangkan makna, "Lisik dalam mendidik, sebagai "slogan" yang kita sampaikan kepada guru agar amanah dalam mendidik anak. Harapannya guru dapat mendidik dengan ikhlas, profesional, dan komunikatif."

Berdasarkan keterangan dari Kepala RA, terdapat 3 (tiga) poin penting dalam upaya suksesi program lisik pada guru (lisik dalam mendidik), yaitu (1) mendidik dengan ikhlas, (2) mendidik secara profesional dan (3) mendidik secara komunikatif.

Pertama, mendidik dengan ikhlas. Konsep ini sejatinya sudah diajarkan kepada guru sebelum ia mengajar. Bahkan, ketika duduk di bangku perkuliahan, para calon guru sudah diingatkan bahwa mengajar adalah bentuk pengabdian atas ilmu yang diperoleh, sehingga ikhlas menjadi suatu keniscayaan. Lebih lanjut, Subahri (2015) menyebut ikhlas sebagai kata yang mudah dihafal tapi "sangat sulit" diaplikasikan. Untuk itu, pimpinan RA Al Hijrah 
Badrul Ulum mendorong pihak guru untuk ikhlas dalam mendidik anak. Dengan demikian, anak akan dididik sepenuh hati, bukan karena gaji atau popularitas di masyarakat. Adapun bentuk dukungan pihak pimpinan agar guru mampu ikhlas dalam mendidik, maka pihak yayasan sangat memperhatikan kesejahteraan para guru, tidak selalu berbentuk uang, melainkan sembako dan alat kebutuhan pokok lainnya.

Kedua, mendidik secara profesional. Maksudnya, guru dituntut untuk dapat bekerja secara profesional, menguasai materi yang diajarkan dan mampu menggunakan metode yang tepat bagi anak usia dini. Sebab, dunia bermain menjadi bagian tak terpisahkan terhadap anak usia dini. Untuk itu, pihak pimpinan men-desain pembelajaran se-nyaman mungkin dengan berbagai fasilitas yang dapat membantu guru untuk mendidik secara profesional.

Ketiga, mendidik secara komunikatif. Maksudnya, guru diminta untuk dapat berkomunikasi dengan anak. Dalam konteks ini, Khairi (2018) memperingatkan bahwa dunia anak berbeda dengan dunia orangtuanya. Meskipun, orangtuanya pernah mengalami masa kanak-kanak, tapi tidak serta-merta menjadikan anak sebagai miniatur orang dewasa. Untuk itu, dibutuhkan upaya ekstra dari guru dalam memahami karakter masing-masing anak didiknya, sehingga mampu bertindak komunikatif.

Berdasarkan uraian di atas, dipahami bahwa mendidik bukanlah sekadar kewajiban menjalankan amanah undang-undang yang terbatas pada jam aktif mengajar. Lebih dari itu, guru RA Al Hijrah Badrul Ulum dituntut secara sadar harus mendidik anak dengan amanah, agar dapat men-sukseskan program lisik, melalui mendidik dengan ikhlas, mendidik secara profesional, dan mendidik secara komunikatif.

\section{Siswa: Lisik dalam Menuntut Ilmu}

Lisik dalam menuntut ilmu secara leksikal berarti rajin menuntut ilmu. Berdasarkan penuturan Kepala RA, lisik dalam menuntut ilmu dimaksudkan sebagai suksesi program lisik yang dikhususkan kepada siswa dalam proses pendidikan yang dilaluinya di RA.

Berikut kutipan wawancara bersama Kepala RA:

“... iya Pak. Di samping kita berlakukan program 'lisik' tadi ke guru, kita juga tujukan kepada anak. Agar anak semangat dalam menuntut ilmu, untuk itu butuh diprogramkan, direncanakan, dan diaktualisasikan. Kalau tidak? Maka jadinya angan-angan." (Hasil Wawancara dengan Jumrah, S.Pd.I., Kepala RA Al Hijrah Badrul Ulum)

Kutipan wawancara di atas, menunjukkan bahwa pihak RA menaruh perhatian lebih kepada anak. Sebab, anak adalah salah satu wujud integritas lembaga. Kualitas anak sebagai calon lulusan menjadi catatan penting bagi masyarakat untuk mempercayakan anak mereka sekolah di RA tersebut. Menurut Assingkily (2020), mematrikan pentingnya menuntut ilmu bagi anak adalah upaya yang tidak sebentar, butuh tahap pengenalan, penghayatan hingga titik kemandirian anak secara sadar untuk belajar. Lebih lanjut, ini merupakan bagian pendidik karakter pada anak usia dini.

Berdasarkan uraian di atas, dipahami bahwa siswa menjadi objek utama dalam setiap siklus proses pendidikan. Atas dasar ini, pihak RA Al Hijrah Badrul Ulum mengkonsep agar siswa lisik dalam menuntut ilmu. Dengan demikian, program lisik dapat menjadi pilar utama dalam menciptakan iklim belajar kondusif di RA Al Hijrah Badrul Ulum, melalui penciptaan pengelolaan pembelajaran yang baik, penanaman sikap dan karakter pada sivitas warga RA, serta penciptaan iklim harmonis antar-warga RA.

\section{SIMPULAN}

Kebijakan internal berupa program lisik dapat menciptakan iklim belajar kondusif di RA Al Hijrah Badrul Ulum, hal ini ditandai dengan harmonisasi antar warga RA, kesadaran dalam mendidik anak sebagai amanah Allah swt.; dan pengelolaan pendidikan yang efektif. Lebih lanjut, temuan ini dapat dijadikan sebagai prototipe bagi lembaga setingkat lainnya untuk mengkreasikan ide dan gagasan yang mengedepankan kebijakan berbasis kearifan lokal dalam menciptakan iklim belajar kondusif yang baik dan ramah bagi anak usia dini. 


\section{UCAPAN TERIMA KASIH}

Peneliti mengucapkan terimakasih banyak kepada para partisipan yang telah bersedia memberi informasi terkait program lisik sebagai upaya RA Al Hijrah dalam menciptakan iklim belajar kondusif. Adapun nama-nama para partisipan tersebut yakni, Ibu Jumrah, S.Pd.I. (Kepala RA Al Hijrah Badrul Ulum) Ibu Siti Molek, S.Pd.I., dan Ibu Darma Taksiah, S.Pd.I. (Guru RA Al Hijrah Badrul Ulum), serta Jumadin dan Masitah (Siswa RA Al Hijrah Badrul Ulum). Semoga kebaikan Ibu-ibu sekalian serta adinda siswa dapat menjadi amal jariyah yang terus mengalir pahalanya. Aamiin.

\section{DAFTAR PUSTAKA}

Aeni, Ani Nur. (2014). "Pendidikan Karakter untuk Siswa SD dalam Perspektif Islam" Mimbar Sekolah Dasar, 1(1). https:// doi.org/10.17509/mimbar-sd.v1i1.863.

Akbar, Irfan Rizka. (2018). “Analisis Kebijakan Kepala Sekolah dalam Upaya Meningkatkan Kompetensi Guru (Study Kasus pada SMK Muhammadiyah Parung)" Tesis. Pamulang: Universitas Pamulang. http:/ / eprints.unpam.ac.id/7320/.

Alfiansyah, M., et.al. (2020). "Kebijakan Internal Madrasah dalam Meningkatkan Mutu Pendidikan di MI Nurul Ummah Kotagede Yogyakarta" MAGISTRA (Media Pengembangan Ilmu Pendidikan Dasar dan Keislaman), 11(1). http://dx.doi.org/10.31942/mgs.v11i1.3460.

Aryanti, Widya. (2010). "Penciptaan Iklim Belajar yang Kondusif Melalui Pendekatan Pengelolaan Kelas di SMK Ardjuna 01 Malang" Skripsi. Malang: Universitas Negeri Malang.

Assingkily, Muhammad Shaleh \& Miswar. (2020). “Urgensitas Pendidikan Akhlak Bagi Anak Usia Dasar (Studi Era Darurat Covid-19)" TAZKIYA, 9(2). http://jurnaltarbiyah.uinsu.ac.id/index.php/tazkiya/article/view/836.

Assingkily, Muhammad Shaleh. (2020). “Living Qur'an dan Hadis di MI Nurul Ummah Kotagede Yogyakarta (Studi Pendidikan Nilai dalam Pembelajaran Al-Qur'an Hadis Kelas 1-3)" Tesis. Yogyakarta: UIN Sunan Kalijaga Yogyakarta.

Chizanah, Lu'luatul \& M. Noor Rochman Hadjam. (2013). "Penyusunan Instrumen Pengukuran Ikhlas" Psikologika: Jurnal Pemikiran dan Penelitian Psikologi, 18(1): 39-49. https:// doi.org/10.20885/psikologika.vol18.iss1.art5.

Creswell, John W. (2009). Research Design Qualitative, Quantitative, and Mixed Methods Approaches. California: SAGE Publications, Inc.

Daniah. (2019). "Nilai Kearifan Lokal Didong dalam Upaya Pembinaan Karakter Peserta Didik" Pionir: Jurnal Pendidikan, 8(1). http://dx.doi.org/10.22373/pjp.v8i1.4585.

Djafri, Novianty. (2020). "Pengaruh Gaya Kepemimpinan dan Budaya Kerja Kepala Sekolah di Pendidikan Anak Usia Dini" Jurnal Obsesi: Jurnal Pendidikan Anak Usia Dini, 4(2). https://obsesi.or.id/index.php/obsesi/article/view/494.

Fata, Ahmad Khoirul. (2012). "Kepemimpinan dalam Perspektif Pemikiran Politik Islam" Jurnal Review Politik, 2(1): http://jurnalfuf.uinsby.ac.id/index.php/JRP/article/view/1001.

Faturahman, Burhanudin Mukhamad. (2018). "Kepemimpinan dalam Budaya Organisasi" MADANI: Jurnal Politik dan Sosial Kemasyarakatan, 10(1): 1-11. http://www.ejurnal.unisda.ac.id/index.php/MADANI/article/view/186.

Firdaus. (2017). "Urgensitas Soft Skills dan Character Building bagi Mahasiswa" Jurnal TAPIS, 13(1). https:// doi.org/10.24042/tps.v13i1.1620.

Fitrah, Muh. (2017). "Peran Kepala Sekolah dalam Meningkatkan Mutu Pendidikan" Jurnal Penjaminan Mutu, 3(1). http://dx.doi.org/10.25078/jpm.v3i1.90.

Handayani, Sri. (2017). “Peningkatan Profesional Guru Melalui Komunikasi Informal” Sekolah Dasar: Kajian Teori dan Praktik Pendidikan, 24(1). http://journal2.um.ac.id/index.php/sd/article/view/1365. 
Haq, Azhar. (2018). "Motivasi Belajar dalam Meraih Prestasi" Vicratina: Jurnal Pendidikan Islam, 3(1). http://riset.unisma.ac.id/index.php/fai/article/view/1081.

Hartono, H Djoko. (2020). “Urgensi Kepemimpinan Inovatif: Studi Kasus Kepala Sekolah Dasar Darul Ulum Pasuruan" Ta'dib: Jurnal Pendidikan Islam dan Isu-isu Sosial, 18(1). http://jurnal.iaihnwpancor.ac.id/index.php/tadib/article/view/348.

Heriyansyah. (2020). “Urgensi Kepemimpinan Guru yang Berkompeten di Sekolah Terhadap Prestasi Belajar Siswa" Islamic Management: Jurnal Manajemen Pendidikan Islam, 3(1). http://dx.doi.org/10.30868/im.v3i01.687.

Hidayat, Asep Saepul. (2012). "Manajemen Sekolah Berbasis Karakter" Asian Journal of $\begin{array}{llll}\text { Innovation and } & \text { (AJIE), }\end{array}$ https://journal.uii.ac.id/ajie/article/view/2580.

Hidayatullah, Muflihun. (2018). "Ikhlas dalam Al-Qur'an: Perspektif Semantik Toshihiko Izutsu" Skripsi. Jakarta: UIN Syarif Hidayatullah Jakarta. http://repository.uinjkt.ac.id/dspace/handle/123456789/40650.

Inanna. (2018). "Peran Pendidikan dalam Membangun Karakter Bangsa yang Bermoral" JEKPEND: Jurnal Ekonomi dan Pendidikan, 1(1). https://doi.org/10.26858/jekpend.v1i1.5057.

Jailani, M. Syahran. (2014). “Teori Pendidikan Keluarga dan Tanggung Jawab Orang Tua dalam Pendidikan Anak Usia Dini" Nadwa: Jurnal Pendidikan Islam, 8(2). https://doi.org/10.21580/nw.2014.8.2.580.

Juliantoro, Mohamad. (2017). "Peran Kepala Sekolah dalam Meningkatkan Mutu Pendidikan" Kependidikan dan Syariah, 5(2). http://www.jurnal.staiba.ac.id/index.php/AlHikmah/article/view/42.

Khairi, Husnuzziadatul. (2018). “Karakteristik Perkembangan Anak Usia Dini dari 0-6 Tahun” Jurnal Warna, 2(2). https://ejournal.iaiig.ac.id/index.php/warna/article/view/87.

Kurniawan, Rahmat. (2017). "Meningkatkan Nilai Karakter Disiplin Melalui Penciptaan Iklim Kelas Kondusif di Kelas IVA SD Negeri 13/I Muara Bulian" Jurnal Edukasi. https://repository.unja.ac.id/1180/.

Mardlotillah, Faridatul. (2013). "Implementasi Kebijakan Sekolah dalam Upaya Pengembangan Pendidikan Karakter Melalui Program Pembiasaan Membaca AlQur'an" Jurnal Kebijakan dan Pengembangan Pendidikan, 1(2): 150-155. http://202.52.52.22/index.php/jkpp/article/view/1563.

Marsalin. (2020). “Membangun Integritas di Satuan Pendidikan Strategi Kepemimpinan Kepala Sekolah, Guru, Orang Tua dan Masyarakat dalam Membentuk Karakter Siswa (Studi Kasus di SDN Antara Kecamatan Trienggadeng Kabupaten Pidie Jaya)" Jurnal Sains Riset, 10(1). http://journal.unigha.ac.id/index.php/JSR/article/view/211.

Maya, Rahendra \& Iko Lesmana. (2018). "Pemikiran Prof. Dr. Mujammil Qomar, M.Ag., tentang Manajemen Pendidikan Islam" Islamic Management: Jurnal Manajemen Pendidikan Islam, 1(2). http:/ / dx.doi.org/10.30868/im.v1i2.281.

Mujib, A. (2012). "Konsep Pendidikan Karakter Berbasis Psikologi Islam" Publikasi Ilmiah UMS. https:// publikasiilmiah.ums.ac.id/xmlui/handle/11617/1746.

Mukti, Nur. (2018). “Kepemimpinan Visioner Kepala Sekolah” Jurnal Kependidikan, 6(1): 71-90. https://doi.org/10.24090/jk.v6i1.1697.

Munir, Muchamad Agus. (2018). "Strategi Pendidikan Islam dalam Menghadapi Globalisasi Ilmu Pengetahuan dan Teknologi" El-Hikmah: Jurnal Kajian dan Penelitian Pendidikan Islam, 12(2). https:/ / doi.org/10.20414/elhikmah.v12i2.593.

Murni. (2016). "Urgensi Komunikasi dalam Manajemen Pendidikan Islam" Jurnal Intelektualita, 4(2). http://103.107.187.25/index.php/intel/article/view/4134.

Ningrum, Epon. (2016). "Pengembangan Sumber Daya Manusia Bidang Pendidikan" Jurnal Geografi Gea, 9(1). https://ejournal.upi.edu/index.php/gea/article/view/1681. 
Pratiwi, Sri Nurabdiah. (2016). "Manajemen Berbasis Sekolah dalam Meningkatkan Kualitas Sekolah" Edutech: Jurnal Ilmu Pendidikan dan Ilmu Sosial, 2(1). https:// doi.org/10.30596/edutech.v2i1.578.

Puspitasari, Heppy. (2018). "Standar Proses Pembelajaran sebagai Sistem Penjaminan Mutu $\begin{array}{llll}\text { Internal } & \text { di Sekolah"Muslim } \quad \text { 339-368. }\end{array}$ http://10.21154/muslimheritage.v2i2.1115.

Rahmah, Yanti Dwi. (2014). "Implementasi Program Sekolah Adiwiyata (Studi pada Sekolah Dasar Negeri Manukan Kulon III/540 Kota Surabaya)" Jurnal Administrasi Publik, 2(4). http://administrasipublik.studentjournal.ub.ac.id/index.php/jap/article/view/447.

Rasyid, Harun. (2015). "Membangun Generasi Melalui Pendidikan Sebagai Investasi Masa Depan" Jurnal Pendidikan Anak, 4(1). https://doi.org/10.21831/jpa.v4i1.12345.

Sabariah. (2014). "Implementasi Pendidikan Sumang dalam Pembinaan Karakter Siswa MTsN Pegasing Kabupaten Aceh Tengah" Tesis. Medan: UIN Sumatera Utara Medan. http://repository.uinsu.ac.id/1432/.

Saifuddin, Ahmad. (2015). "Eksistensi Kurikulum Pesantren dan Kebijakan Pendidikan" Jurnal Pendidikan Agama Islam, 3(1): 207-234. https:/ / doi.org/10.15642/jpai.2015.3.1.207-234.

Sakban, et.al., (2019). "Manajemen Sumber Daya Manusia” Alignment: Journal of Administration $\begin{array}{lll}\text { and } \quad \text { Educational 2(1): 93-104. } & \text { Magement, }\end{array}$ https:// doi.org/10.31539/alignment.v2i1.721.

Sarjana, Sri \& Nur Khayati. (2016). "Pengaruh Etika, Perilaku, dan Kepribadian Terhadap Integritas Guru" Jurnal Pendidikan dan Kebudayaan, 1(3). https://dx.doi.org/10.24832/jpnk.v1i3.450.

Sastrawan, Ketut Bali \& Kadek Hengki Primayana. (2020). “Urgensi Pendidikan Humanisme dalam Bingkai A Whole Person" Haridracarya: Jurnal Pendidikan Agama Hindu, 1(1). http://jurnal.stahnmpukuturan.ac.id/index.php/haridracarya/article/view/619.

Subahri. (2015). "Aktualisasi Akhlak dalam Pendidikan" Islamuna: Jurnal Studi Islam, 2(2). http://dx.doi.org/10.19105/islamuna.v2i2.660.

Solichin, Mujianto. (2015). "Implementasi Kebijakan Pendidikan dan Peran Birokrasi" Religi: Jurnal Studi Islam, 6(2). http://journal.unipdu.ac.id/index.php/religi/article/view/486.

Sudrajat, Cucu Jajat, et.al. (2021). "Strategi Kepala TK dalam Meningkatkan Mutu Pendidikan pada Masa Pandemi Covid 19" Jurnal Obsesi: Jurnal Pendidikan Anak Usia Dini, 5(1). https://obsesi.or.id/index.php/obsesi/article/view/582.

Sumintono, Bambang. (2013). "Sekolah Unggulan: Pendekatan Pengembangan Kapasitas Sekolah" Jurnal Manajemen Pendidikan, 1(1).

Supardi, U.S. (2015). "Arah Pendidikan di Indonesia dalam Tataran Kebijakan dan Implementasi" Formatif: Jurnal Ilmiah Pendidikan MIPA, 2(2). http://dx.doi.org/10.30998/formatif.v2i2.92.

Supriadi, Acep. (2011). "Analisis Prakondisi Implementasi Kebijakan Peningkatan Kompetensi Guru" Jurnal Pendidikan dan Pembelajaran (JPP), $18(1)$. http://journal.um.ac.id/index.php/pendidikan-danpembelajaran/article/view/2756.

Tanggela, M. (2013). “Analisis Implementasi Kebijakan Pengelolaan Sarana dan Prasarana Sekolah di SMP Negeri 2 Batu" Jurnal Kebijakan dan Pengembangan Pendidikan, 1(1). http://202.52.52.22/index.php/jkpp/article/view/1505.

Thohir, Umar Faruq. (2018). “Konsep Keluarga dalam Perspektif Al-Qur'an” Asy-Syari'ah: Jurnal Hukum Islam, 4(2): 203-222. https:/ / doi.org/10.36835/assyariah.v4i2.109.

Tidjani, Aisyah. (2017). “Manajemen Lembaga Pendidikan Islam Menghadapi Tantangan Globalisasi" Reflektika, 12(1): 96-133. http://ejournal.idia.ac.id/index.php/reflektika/article/view/74. 
Tillah, Rizqi Mardha. (2019). "Aceh Tengah Racesource" Jurnal Ilmiah Mahasiswa, 3(4). http://www.jim.unsyiah.ac.id/ArsitekturPWK/article/view/15023.

Wahyu, Ellyn Eka. (2020). “Urgensi Kepemimpinan Transformasional dan Kecerdasan Emosional pada Perusahaan dalam Merespons Pandemi Covid-19" Prosiding Seminar Nasional Akuntansi, Manajemen, dan Keuangan, 1(1). https:// prosiding.polinema.ac.id/sngbs/index.php/snamk/article/view/285.

Wahyuni, Sri, et.al. (2020). "'Mendidik dengan Hati dan Keteladanan': Branding untuk Menumbuhkan Karakter Pendidik Anak Usia Dini" JUPIIS: Jurnal Pendidikan Ilmu-ilmu Sosial, 12(2). https://doi.org/10.24114/jupiis.v12i2.17294.

Wandasari, Yulisa. (2017). “Implementasi Gerakan Literasi Sekolah (GLS) sebagai Pembentuk Pendidikan Berkarakter" Jurnal Manajemen, Kepemimpinan, dan Supervisi Pendidikan, 2(2). http:/ / dx.doi.org/10.31851/jmksp.v2i2.1480.

Widyaningrum, Heny Kusuma \& Fauzatul Ma'rufah Rahmanumeta. (2016). "Pentingnya Strategi Pembelajaran Inovatif dalam Menghadapi Kreativitas Siswa di Masa Depan" Proceedings International Seminar FoE (Faculty of Education). http://prosiding.unipma.ac.id/index.php/PIS-FoE/article/view/98.

Yanto, Murni \& Irwan Fathurrochman. (2019). "Manajemen Kebijakan Kepala Madrasah dalam Meningkatkan Mutu Pendidikan" Jurnal Konseling dan Pendidikan, 7(3): 123-130. http://repository.iaincurup.ac.id/160/.

Yin, Robert K. (2009). Case Study Research: Design and Methods. California: SAGE Inc.

Yuliana, Rahmi. (2012). "Peran Komunikasi dalam Organisasi" Jurnal STIE Semarang, 4(3). http://jurnal3.stiesemarang.ac.id/index.php/jurnal/article/view/162.

Yusria. (2018). "Iklim Kelas yang Kondusif untuk Membangun Pendidikan Karakter Kemandirian di Sekolah Dasar Islam Terpadu Nurul Ilmi Telanaipura Kota Jambi" PEJ (Primary Education Journal), $1(2)$ : 88-92. http://pej.ftk.uinjambi.ac.id/index.php/PEJ/article/view/12. 